\title{
Uji Aktivitas Antibakteri Sediaan Obat Kumur dari Ekstrak Etanol 70\% Batang Sambung Nyawa (Gynura procumbens (Lour.) Merr.) terhadap Bakteri Streptococcus mutans
}

\section{Antibacterial Activity of Longevity Spinach (Gynura Procumbens (Lour.) Merr.) Bark Extract In $70 \%$ Ethanol and It's Mouthwash Formula Against Streptococcus Mutans}

\author{
Dame Gurning ${ }^{1}$, Dicki Nathaniel ${ }^{1}$, Okpri Meila ${ }^{2}$, Zuraida Sagala ${ }^{1}$ \\ ${ }^{1}$ Fakultas Farmasi Universitas 17 Agustus 1945 Jakarta \\ ${ }^{2}$ Fakultas Farmasi Institut Sains dan Teknologi Nasional, Jakarta \\ Email: damegurning715@gmail.com; okprimeila@gmail.com
}

\begin{abstract}
Abstrak
Karies gigi merupakan suatu masalah pada mulut yang disebabkan oleh bakteri Streptococcus mutans, prevalensi karies gigi telah mencapai hingga $60 \%$ di Indonesia. Penggunaan obat kumur dinilai efektif, karena dapat membersihkan mulut sampai ke sela-sela gigi. Pada penelitian ini dilakukan uji aktivitas antibakteri sediaan obat kumur dari ekstrak etanol batang sambung nyawa (Gynura procumbens (Lour.) Merr.) terhadap bakteri Streptooccus mutans dengan seri konsentrasi ekstrak 2,5\%; 5\% dan 10\%. Pengujian aktivitas antibakteri dilakukan dengan menggunakan metode difusi cakram. Uji aktivitas antibakteri ekstrak batang sambung terhadap bakteri Streptococcus mutans dilakukan sebagai uji pendahuluan dan hasilnya didapatkan Konsentrasi Hambat Minimum (KHM) terhadap pertumbuhan bakteri Streptococcus mutans ada pada konsentrasi ekstrak 2,5\% dengan rata-rata zona hambatan sebesar 7,80 $\mathrm{mm}$. Rata-rata zona hambat terhadap pertumbuhan bakteri Streptococcus mutans lebih tinggi dalam sediaan obat kumur dibandingkan dengan bentuk ekstrak yang masih murni, dikarenakan adanya beberapa bahan pada formulasi sediaan obat kumur yang dapat berfungsi sebagai agen antibakteri, seperti gliserin, menthol dan natrium benzoat. Zona hambatan terhadap pertumbuhan bakteri Streptococcus mutans meningkat seiring dengan meningkatnya konsentrasi dari ekstrak etanol batang sambung nyawa. Evaluasi stabilitas dari sediaan obat kumur meliputi pemeriksaan organoleptis, homogenitas dan $\mathrm{pH}$ yang dilakukan selama empat minggu penyimpanan pada suhu ruang menunjukkan hasil yang stabil.

Kata kunci: Obat kumur, Antibakteri, Gynura procumbens (Lour.) Merr, Streptococcus mutans, difusi cakram
\end{abstract}

\begin{abstract}
One of the most prominent problems occurring in the oral cavity is dental caries. This very prevalent disease (about $60 \%$ of cases in Indonesia) is caused by the bacteria Streptococcus mutans. The usage of mouthwash is deemed effective for its ability to cleanse the oral cavity, even in the gaps between teeth. In this study, a series of test was done to confirm longevity spinach's bark extract and its mouthwash formula's antibacterial activity; particularly against Streptococcus mutans. The extract was made into concentrations of 2,5\%; 5\%; and $10 \%$ using serial dissolution method. The test was done using the disc diffusion method. The extracts were tested first to confirm whether or not they have antibacterial activity against Streptococcus mutans. Results stated that the extracts do indeed possess some degree of antibacterial activity. The minimum inhibitory concentration (MIC) from this test was found to be 2,5\%; with an average inhibitory zone diameter of 7,80 $\mathrm{mm}$. the average inhibitory zones given by the mouthwash formula is relatively larger than that of each extract. This is due to the fact that many of the formulas' excipients used in the making of the mouthwash like glycerin, menthol, and benzoic sodium have been known to exhibit antibacterial tendencies. The inhibitory zones diameter grow larger with the increase of extract's concentration. The mouthwash formulas' stability was evaluated during the course of 4 weeks of storage in room temperature. The parameters evaluated included organoleptic parameters, homogeneity, and acidity. It was concluded that the formulas do not show any signs of instability.
\end{abstract}

Keywords: Mouthwash, antibacterial, Gynura procumbens (Lour.) Merr.), Streptococcus mutans, disc diffusion 


\section{PENDAHULUAN}

Mikroorganisme yang paling banyak tumbuh di dalam rongga mulut adalah Streptococcus sp, yang berperan dalam tahap awal terjadinya karies pada gigi. Pada plak gigi tersebut, ditemukan koloni bakteri Streptococcus mutans (Pratiwi, 2008). Streptococcus mutans merupakan bakteri utama penyebab terjadinya karies gigi. Streptococcus mutans juga merupakan suatu bakteri asidogenik yang dapat menghasilkan senyawa asam, yang dapat menyebabkan penimbunan senyawa asam pada gigi, sehingga dapat menyebabkan terjadinya dekalsifikasi (hilangnya kalsium) dan juga terkikisnya permukaan gigi, yang nantinya dapat menyebabkan terjadinya karies gigi (Putri dkk, 2010).

Obat kumur secara umum dapat didefinisikan sebagai sediaan larutan dengan rasa yang nyaman, mengandung antimikroba dan juga berguna untuk menyegarkan mulut (Rieger, 2001). Pada umumnya, sediaan obat kumur komersial yang beredar dipasaran mengandung kadar alkohol yang cukup tinggi, dimana penggunaan obat kumur dengan kandungan alkohol sebesar 25\% atau lebih, dapat meningkatkan risiko tumbulnya kanker mulut, tenggorokan dan faring sekitar 50\% (Bahna et al, 2007).

Alternatif lain yang dapat menggantikan obat kumur komersial tersebut adalah dengan memakai ekstrak bahan alam, salah satunya adalah ekstrak batang sambung nyawa (Gynura procumbens (Lour.) Merr.) yang sudah diteliti sebelumnya oleh Aryanti dan kawan-kawan dapat bertindak sebagai agen antibakteri. Berdasarkan penelitian tersebut, ekstrak etanol batang sambung nyawa yang baru berumur satu bulan dengan konsentrasi $100 \mathrm{mg} / \mathrm{mL}$ dapat memberikan zona hambat terhadap bakteri Staphylococcus aureus sebesar $12 \mathrm{~mm}$ dan sebesar $9 \mathrm{~mm}$ terhadap bakteri Escherichia coli (Aryanti dkk, 2006).

Sambung nyawa (Gynura procumbens (Lour). Merr.) merupakan suatu tanaman obat yang banyak di temukan di daerah Asia tropis, seperti China, Thailand, Indonesia, Malaysia dan Vietnam. Berdasarkan penelitian yang telah dilakukan secara in vitro dan in vivo, sambung nyawa menunjukkan beberapa aktivitas biologis, seperti antihipertensi, cardioprotektif, antihiperglikemik, meningkatkan fertilitas, antikanker, antimikroba, antioksidan, antiinflamasi dan proteksi terhadap organ (Tan et al, 2016).

Pada penelitian ini diharapkan ekstrak etanol batang sambung nyawa (Gynura procumbens (Lour). Merr) dapat bersifat sebagai antibakteri terhadap bakteri Streptococcus mutans.

\section{METODE PENELITIAN}

Penelitian ini dilaksanakan selama lima bulan dari bulan April sampai Agustus 2017. Penelitian dilakukan di Laboratorium Penelitian dan Mikrobiologi Fakultas Farmasi Universitas 17 Agustus 1945 Jakarta, serta Laboratorium Balai Penelitian Tanaman Rempah dan Obat (BALITRO).

\section{Alat}

Alat-alat yang digunakan dalam penelitian ini meliputi kompor listrik (Maspion), botol kaca gelap, rotary evaporator (Buchi), autoklaf (Hirayama), timbangan analitik (Boeco), Alat-alat gelas (Iwaki Pyrex), pipet tetes, cawan petri, ose bulat, bunsen, kertas cakram (Oxoid), inkubator (Memmert), jangka sorong (Tricle Brand), mikroskop (Yazumi), laminar air flow, pH meter (Hanna) dan kertas saring.

\section{Bahan}

Bahan-bahan yang digunakan dalam penelitian ini meliputi batang sambung nyawa yang diperoleh dari Bogor, etanol 70\%, gliserin, natrium benzoat, aquadest, menthol, natrium lauril sulfat, media Mueller Hinton Darah, $\mathrm{NaCl} 0,9 \%, \mathrm{H}_{2} \mathrm{SO}_{4}, \mathrm{BaCl}_{2}, \mathrm{HCl}$, amilalkohol, pereaksi meyer, dragendorf, Bouchardad, $\mathrm{FeCl}_{3}$, bakteri Streptococcus mutans (ATCC 31987) yang diperoleh dari Laboratorium Mikrobiologi Fakultas Kedokteran Universitas Indonesia.

\section{Pembuatan Ekstrak Etanol Batang Sambung Nyawa}


Tabel 1. Komposisi Obat Kumur

\begin{tabular}{|c|c|c|c|c|c|c|}
\hline \multirow[t]{2}{*}{ Bahan } & \multirow[t]{2}{*}{ Kegunaan } & \multicolumn{4}{|c|}{ Komposisi (\%) } & \multirow{2}{*}{$\begin{array}{l}\text { Standar } \\
(\%)\end{array}$} \\
\hline & & FI & FII & FIII & FIV & \\
\hline $\begin{array}{l}\text { Ekstrak etanol batang } \\
\text { sambung nyawa }\end{array}$ & Zat aktif & 0 & 2.5 & 5 & 10 & - \\
\hline Gliserin & Kosolven & 7,5 & 7,5 & 7,5 & 7,5 & $<20$ \\
\hline Natrium lauril sulfat & Pembusa & 1 & 1 & 1 & 1 & $1-2$ \\
\hline Natrium benzoat & Pengawet & 0,1 & 0,1 & 0,1 & 0,1 & $0,01-0,1$ \\
\hline Menthol & Perisa & 0,5 & 0,5 & 0,5 & 0,5 & $0,1-2$ \\
\hline Akuades & Pelarut & 100 & 100 & 100 & 100 & - \\
\hline
\end{tabular}

Maserasi dilakukan dengan cara memasukkan 1000 gram serbuk batang sambung nyawa ke dalam botol kaca gelap, kemudian ditambahkan $3000 \mathrm{~mL}$ pelarut etanol $70 \%$ dan dibiarkan selama 3 hari sambil sesekali diaduk. Hasil maserasi kemudian disaring untuk memisahkan antara cairan etanol dengan ampasnya. Kemudian dilakukan remaserasi selama 3 hari untuk mendapatkan hasil zat aktif yang lebih banyak. Proses Remaserasi dilakukan sebanyak 2 kali. Setelah itu, hasil ekstrak cair (etanol) diuapkan dengan menggunakan rotary evaporator untuk memperoleh ekstrak kental.

\section{Pemeriksaan Karakteristik Ektrak}

Pemeriksaan karakteristik ekstrak meliputi pemeriksaan organoleptis, kadar air, perhitungan rendemen dan skrining fitokimia. Pembuatan Larutan Uji Ekstrak

Larutan uji dibuat ke dalam tiga seri konsentrasi yaitu 2,5\%; $5 \%$, dan $10 \%$ dalam satuan (b/v). Kontrol positif yang digunakan adalalah obat kumur herbal yang beredar dipasaran, sekaligus digunakan sebagai kompetitor. Sedangkan kontrol negatifnya digunakan aquadest.

Rancangan Formula Sediaan Obat Kumur

Formula sediaan obat kumur dibuat dalam satuan $(\mathrm{b} / \mathrm{v})$ seperti yang terlihat pada tabel 1.

\section{Evaluasi Formula}

Evaluasi fisik dan kimia sediaan obat kumur dari ekstrak batang sambung nyawa yang dibuat meliputi uji organoleptis, uji $\mathrm{pH}$ sediaan dan uji homogenitas sediaan.

\section{Pembuatan Media Kultur Bakteri}

Media kultur yang digunakan pada penelitian ini untuk pembiakan bakteri Streptococcus mutans adalah media Mueller Hinton Darah. Media Mueller Hinton Darah dibuat dalam Erlenmeyer dengan cara mengkombinasikan bahan-bahan dari Mueller Hinton Agar dengan 5\% darah domba. Lalu dibungkus dengan kertas perkamen, kemudian disterilkan di dalam autoklaf dengan temperatur sebesar $121{ }^{\circ} \mathrm{C}$ selama 20 menit.

\section{Peremajaan Bakteri Uji}

Peremajaan bakteri uji dilakukan dengan cara menanam bakteri murni pada media Mueller Hinton Darah dalam cawan petri. Setelah dilakukan penanaman, selanjutnya biakan tersebut dimasukkan ke dalam inkubator dengan suhu sebesar $37{ }^{\circ} \mathrm{C}$ selama 24 jam. Setelah itu, kemurnian bakteri Streptococcus mutans di cek dengan pewarnaan gram, kemudian dilihat bentuk dan koloninya pada mikroskop.

\section{Penyetaraan Standar Kekeruhan Bakteri}

Bakteri murni ditanami ke dalam larutan suspensi $\mathrm{NaCl}$ 0,9\% dengan menggunakan ose steril, dikocok dan kemudian tingkat kekeruhan larutan disetarakan dengan larutan standar McFarland 0,5.

\section{Pengujian Aktivitas Antibakteri}

Setelah selesai dilakukan pembiakan bakteri pada cawan petri, selanjutnya diambil lima kertas cakram kosong dan masingmasing direndam ke dalam larutan ekstrak etanol batang sambung nyawa konsentrasi $2,5 \% ; 5 \% ; 10 \%$, kontrol positif dan kontrol 
negatif. Setelah itu dipindahkan ke dalam cawan petri steril dan didiamkan selama 30 menit. Kemudian kelima kertas cakram tersebut diletakkan diatas permukaan media yang sudah sebelumnya sudah dilakukan pembiakan bakteri. Lalu, cawan petri tersebut dimasukkan ke dalam inkubator dengan suhu sebesar $37{ }^{\circ} \mathrm{C}$ dan di inkubasi selama 24 jam. Pengujian diatas dilakukan sebanyak tiga kali pengulangan (triplo). Lalu, hasil zona hambat yang terbentuk diukur menggunakan jangka sorong, kemudian dicatat. Hal yang sama juga dilakukan pada pengujian aktivitas antibakteri sediaan obat kumur, bedanya kontrol negatif yang digunakan pada sediaan obat kumur adalah obat kumur yang pembuatannya tanpa penambahan ekstrak etanol batang sambung nyawa (Formula I).

\section{HASIL DAN PEMBAHASAN}

Hasil pemeriksaan organoleptis menunjukkan bentuk ekstrak yang kental, berwarna cokelat tua kehijauan, beraroma khas ekstrak, serta berasa hambar (Tabel 1). Rendemen ekstrak yang didapatkan adalah sebesar 5,79\% dan kadar air sebesar 6,54\%. Hasil skrining fitokimia dapat dilihat pada tabel 2.

Tabel 2. Hasil Skrining Fitokimia

\begin{tabular}{lc}
\hline Kandungan kimia & Hasil \\
\hline Alkaloid & + \\
Saponin & + \\
Tanin & + \\
Fenolik & + \\
Flavonoid & + \\
Triterpenoid & + \\
Steroid & - \\
Glikosida & + \\
\hline
\end{tabular}

Berdasarkan hasil dari tabel 3, zona hambat terbesar ekstrak batang sambung nyawa terhadap bakteri Streptococcus mutans ada pada konsentrasi $10 \%$ dengan rata-rata zona hambat sebesar $8,45 \mathrm{~mm}$.

Sedangkan berdasarkan hasil dari tabel 4 , zona hambat terbesar juga ada pada konsentrasi $10 \%$, dengan rata-rata zona hambat sebesar 11,80 $\mathrm{mm}$ terhadap pertumbuhan bakteri Streptococcus mutans.
Untuk kedua perlakuan baik ekstrak dan sediaan obat kumur, keduanya sama-sama menunjukkan peningkatan rata-rata zona hambat terhadap pertumbuhan bakteri Streptococcus mutans seiring dengan meningkatnya konsentrasi dari ekstrak tersebut.

Tabel 3. Hasil Uji Aktivitas Antibakteri Larutan Ekstrak

Kelompok perlakuan Diameter zona hambat $(\mathrm{mm})$

\begin{tabular}{lrll}
\hline Kontrol positif & 0 & \pm & 0 \\
Kontrol negatif & 0 & \pm & 0 \\
Ekstrak 2,5\% & 7,80 & \pm & 0,13 \\
Ekstrak 5\% & 8,18 & \pm & 0,08 \\
Ekstrak 10\% & 8,45 & \pm & 0,15 \\
\hline
\end{tabular}

Tabel 4. Hasil Uji Aktivitas Antibakteri Sediaan Obat Kumur

\begin{tabular}{|c|c|}
\hline Kelompok perlakuan & $\begin{array}{l}\text { Diameter zona } \\
\text { hambat }(\mathrm{mm})\end{array}$ \\
\hline Kontrol positif & $0,00 \pm 0$ \\
\hline F1 (Ekstrak 0\%) & $7,93 \pm 0$ \\
\hline F2 (Ekstrak 2,5\%) & $9,47 \pm 0,25$ \\
\hline F3 (Ekstrak 5\%) & $10,60 \pm 0,40$ \\
\hline F4 (Ekstrak 10\%) & $11,80 \pm 0,48$ \\
\hline
\end{tabular}

Rata-rata zona hambat terhadap pertumbuhan bakteri Streptococcus mutans lebih tinggi jika ekstrak diformulasikan ke dalam sediaan obat kumur dibandingkan dengan bentuk ekstrak yang masih murni. Hal tersebut dikarenakan pada formulasi sediaan obat kumur ditambahkan bahan tambahan yang juga dapat berfungsi sebagai zat antibakteri, seperti gliserin, menthol dan natrium benzoat.

Konsentrasi hambat minimum (KHM) ekstrak etanol batang sambung nyawa (Gynura procumbens (Lour.) Merr.) terhadap pertumbuhan bakteri Streptococcus mutans ada pada konsentrasi ekstrak 2,5\% dengan rata-rata zona hambatan sebesar 7,80 $\mathrm{mm}$.

Berdasarkan hasil analisis statistik menggunakan One Way ANOVA antara 
Tabel 5. Pengamatan organoleptis sediaan

\begin{tabular}{|c|c|c|c|c|c|c|}
\hline \multirow[t]{2}{*}{ Formulasi } & \multirow{2}{*}{$\begin{array}{c}\text { Parameter } \\
\text { organolepti } \\
\text { s }\end{array}$} & \multicolumn{5}{|c|}{ Pengamatan minggu ke- } \\
\hline & & 0 & 1 & 2 & 3 & 4 \\
\hline \multirow{4}{*}{$\begin{array}{c}\text { F1 } \\
(\text { Ekstrak } \\
0 \%)\end{array}$} & Rasa & sedikit manis & sedikit manis & sedikit manis & sedikit manis & sedikit manis \\
\hline & Aroma & khas menthol & khas menthol & khas menthol & khas menthol & khas menthol \\
\hline & Warna & bening & bening & bening & bening & bening \\
\hline & Bentuk & larutan & larutan & larutan & larutan & larutan \\
\hline \multirow{4}{*}{$\begin{array}{c}\mathrm{F} 2 \\
(\text { Ekstrak } \\
2,5 \%)\end{array}$} & Rasa & sedikit manis & sedikit manis & sedikit manis & sedikit manis & sedikit manis \\
\hline & Aroma & khas menthol & khas menthol & khas menthol & khas menthol & khas menthol \\
\hline & Warna & coklat tua & coklat tua & coklat tua & coklat tua & coklat tua \\
\hline & Bentuk & larutan & larutan & larutan & larutan & larutan \\
\hline \multirow{4}{*}{$\begin{array}{c}\text { F3 } \\
\text { (Ekstrak } \\
5 \%)\end{array}$} & Rasa & hambar & hambar & hambar & hambar & hambar \\
\hline & Aroma & khas menthol & khas menthol & khas menthol & khas menthol & khas menthol \\
\hline & Warna & coklat tua & coklat tua & coklat tua & coklat tua & coklat tua \\
\hline & Bentuk & larutan & larutan & larutan & larutan & larutan \\
\hline \multirow{5}{*}{$\begin{array}{c}\text { F4 } \\
(\text { Ekstrak } \\
10 \%)\end{array}$} & Rasa & sedikit manis & sedikit manis & sedikit manis & sedikit manis & sedikit manis \\
\hline & Aroma & khas menthol & khas menthol & khas menthol & khas menthol & khas menthol \\
\hline & Warna & coklat tua & coklat tua & coklat tua & coklat tua & coklat tua \\
\hline & & kehijauan & kehijauan & kehijauan & kehijauan & kehijauan \\
\hline & Bentuk & larutan & larutan & larutan & larutan & larutan \\
\hline
\end{tabular}

perlakuan peningkatan konsentrasi ekstrak terhadap zona hambat pertumbuhan bakteri

Streptococcus mutans yang dihasilkan, menunjukkan nilai signifikansi 0,000 $(\mathrm{p}<0,05)$ baik pada uji aktivitas antibakteri ekstrak batang sambung nyawa, maupun formulasinya dalam sediaan obat kumur. Hal tersebut menyatakan bahwa peningkatan konsentrasi ekstrak etanol batang sambung nyawa memberikan perbedaan yang bermakna terhadap zona hambat pertumbuhan bakteri Streptococcus mutans.

Sebagai kontrol positif digunakan obat kumur herbal yang beredar di pasaran sebagai kompetitor yang berkhasiat untuk obat sariawan. Hasilnya adalah obat kumur tersebut yang dipakai sebagai kontrol positif tidak memberikan zona hambatan terhadap pertumbuhan bakteri Streptococcus mutans. Hal tersebut dapat terjadi dikarenakan obat kumur herbal tersebut yang lebih ditujukan sebagai obat sariawan, di mana penyebab utama dari sariawan adalah jamur Candida albicans, bukan bakteri Streptococcus mutans yang merupakan bakteri utama penyebab karies gigi.

Hasil pemeriksaan organoleptis sediaan obat kumur dari ekstrak etanol batang sambung nyawa dapat dilihat pada tabel 5 . Berdasarkan tabel 5, tidak terjadi perubahan dari segi rasa, aroma, bentuk dan juga warna dari sediaan obat kumur yang dibuat dalam periode penyimpanan selama empat minggu pada suhu kamar. Hal tersebut menandakan bahwa sediaan obat kumur tersebut bersifat stabil pada suhu kamar.

Hasil pemeriksaan homogenitas sediaan obat kumur dari ekstrak etanol batang sambung nyawa dapat dilihat pada tabel 6 . Berdasarkan hasil dari tabel 6, seluruh formula sediaan obat kumur dari ekstrak batang sambung nyawa menunjukkan hasil yang homogen setelah dilakukan penyimpanan selama 4 minggu pada suhu kamar. 
Tabel 6. Homogenitas sediaan obat kumur selama penyimpanan 4 minggu

\begin{tabular}{cccccc}
\hline Formulasi & \multicolumn{5}{c}{ Pengamatan minggu ke- } \\
\cline { 2 - 6 } & 0 & 1 & 2 & 3 & 4 \\
\hline F1 (Ekstrak 0\%) & homogen & homogen & homogen & homogen & homogen \\
F2 (Ekstrak 2,5\%) & homogen & homogen & homogen & homogen & homogen \\
F3 (Ekstrak 5\%) & homogen & homogen & homogen & homogen & homogen \\
F4 (Ekstrak 10\%) & homogen & homogen & homogen & homogen & homogen \\
\hline
\end{tabular}

Tabel 7. Hasil pemeriksaan pH sediaan obat kumur selama 4 minggu

\begin{tabular}{lccccc}
\hline \multirow{2}{*}{ Formulasi } & \multicolumn{5}{c}{$\mathrm{pH}$ obat kumur minggu ke- } \\
\cline { 2 - 6 } & 0 & 1 & 2 & 3 & 4 \\
\hline F1 (Ekstrak 0\%) & 6,44 & 6,44 & 6,43 & 6,42 & 6,42 \\
F2 (Ekstrak 2,5\%) & 6,15 & 6,14 & 6,14 & 6,13 & 6,13 \\
F3 (Ekstrak 5\%) & 6,16 & 6,15 & 6,14 & 6,13 & 6,12 \\
F4 (Ekstrak 10\%) & 5,83 & 5,82 & 5,82 & 5,81 & 5,80 \\
\hline
\end{tabular}

Hasil pemeriksaan $\mathrm{pH}$ sediaan obat kumur dari ekstrak etanol batang sambung nyawa dapat dilihat pada tabel 7. Berdasarkan hasil dari tabel 7 , Penurunan nilai $\mathrm{pH}$ terjadi seiring dengan meningkatnya konsentrasi ekstrak, hal tersebut menunjukkan bahwa ekstrak etanol batang sambung nyawa bersifat sedikit asam.

Setelah penyimpanan selama 4 minggu dengan dilakukan pengamatan setiap minggunya, terlihat bahwa sediaan obat kumur dari ekstrak batang sambung nyawa tersebut tidak mengalami penurunan $\mathrm{pH}$ yang berarti, sehingga dapat dikatakan bahwa $\mathrm{pH}$ dari setiap formula sediaan obat kumur tersebut stabil dalam penyimpanan selama 4 minggu pada suhu kamar.

\section{KESIMPULAN}

Berdasarkan hasil penelitian, dapat disimpulkan bahwa ekstrak etanol 70\% batang sambung nyawa (Gynura procumbens (Lour.) Merr.) dapat diformulasikan ke dalam bentuk sediaan obat kumur dan berkhasiat sebagai antibakteri terhadap bakteri Streptococcus mutans.

\section{Daftar Pustaka}

Aryanti, dkk. 2006. Isolasi dan Uji Antibakteri Batang Sambung Nyawa (Gynura procumbens Lour) Umur Panen 1,4 dan 7 Bulan. Jurnal Bahan Alam Indonesia ISSN 1412-2855 Vol. 6, No.2. Jakarta.

Bahna P, Hanna HA, Dvorak T, Vaporciyan A, Chambers M, and Raad I. 2007. Antiseptic effect of a novel alcohol-free mouthwash: A convenient prophylactic alternative for high risk patients. Oral Oncology J. 43:159-64.

Pratiwi, S.T., 2008. Mikrobiologi Farmasi. Erlangga Medical Series. Jogjakarta.

Putri MH, Herijulianti E, Nurjannah N. 2010. Ilmu Pencegahan Penyakit Jaringan Keras dan Jaringan Pendukung Gigi. Jakarta: EGC.

Rieger, M. 2001. Harry's Cosmetology, $8^{\text {th }}$ edition. Hal: 745 - 753. Chemical Publishing. 
Tan, Hui-Li., Chan, Kok-Gan., Pusparajah, P., Lee, Learn-Han., Goh, Bey-Hing. 2016. Gynura procumbens: An Overview of The Biological Activities. License: CC-BY. Vol.7, Article 62. 